\title{
Potential mineral resources of the Chilean offshore: an overview
}

\author{
Marcelo García ${ }^{1,2}, * J o r g e ~ C o r r e a{ }^{1,2}, V^{\prime}$ ctor Maksaev ${ }^{3}$, Brian Townley $^{1,2}$ \\ ${ }^{I}$ Advanced Mining Technology Center, Universidad de Chile. Av. Tupper 2007, Santiago, Chile. \\ mgarciagodoy@ing.uchile.cl; jocorrea@ing.uchile.cl; btownley@ing.uchile.cl \\ 2 Departamento de Geología, Universidad de Chile, Plaza Ercilla 803, Santiago, Chile. \\ 3 Alicahue 7861, La Florida, Santiago 8271196, Chile. \\ victormaksaev@gmail.com \\ *Corresponding author: jocorrea@ing.uchile.cl
}

\begin{abstract}
The seabed included in the Chilean Exclusive Economic Zone (EEZ) has proper conditions to originate and host different ore deposits, but its geological knowledge is scarce and scattered. The existent studies are very limited in terms of geochemical and mineralogical analyses. The most significant non-energetic mineral resources off Chile correspond to Fe-Mn nodules and crusts, phosphorite deposits, gold and titanium placer deposits and massive sulfide deposits. Fe-Mn nodule sites occur in abyssal plains and seamounts, and around volcanic islands, at depths from 2,890 to $4,332 \mathrm{~m}$, and can contain important concentrations of $\mathrm{Cu}$ and $\mathrm{Ni}$ (up to $1.38 \% \mathrm{Cu}+\mathrm{Ni}$ ) and $\mathrm{Co}$ (up to $0.53 \%$ ). Co-rich Fe-Mn crust occurrences have been reported around the Rapanui and Salas y Gómez islands, with $\mathrm{Cu}+\mathrm{Ni}$ contents up to $0.3 \%$. Phosphorite sites occur in Holocene sedimentary beds of the continental shelf off Peru and northern Chile, with $\mathrm{P}_{2} \mathrm{O}_{5}$ average content of $22.6 \%$. Gold placer deposits are found in beaches and channels of southern Chile and may extend offshore probably in submarine canyons. Titanium placer deposits have been evaluated in different beaches of Chile and could also be continued offshore. Platinum anomalies have been found in channels and bays of southernmost Chile. No samples of Volcanogenic Massive Sulfide (VMS) mineralization are known in the Chilean EEZ to date. However, samples of hydrothermal vents, with potential for polymetallic VMS type mineralization, have been recovered around the Rapanui Island, and several seamount and volcanic island chains indicate favorable conditions for formation and preservation of these ore-deposits. The available geological information on the seabed of the Chilean EEZ is insufficient to estimate the real potential of its non-energetic mineral resources.
\end{abstract}

Keywords: Mineral deposits, Seabed, Chilean Exclusive Economic Zone.

RESUMEN. Recursos minerales potenciales del fondo marino chileno: una revisión. El subsuelo marino comprendido por la Zona Económica Exclusiva (ZEE) de Chile tiene condiciones propicias para originar y hospedar diferentes depósitos minerales, pero su conocimiento geológico es escaso y disperso. Los estudios existentes son muy limitados en cuanto a análisis geoquímicos y mineralógicos. Los recursos minerales no-energéticos más significativos, costa afuera de Chile, corresponden a: nódulos y costras de Fe-Mn, depósitos de fosforitas, depósitos de placeres de oro y titanio y depósitos de sulfuros masivos. Los sitios de nódulos de Fe-Mn se encuentran en planicies abisales y montes submarinos, y alrededor de islas volcánicas, a profundidades de 2.890 a $4.332 \mathrm{~m}$, y pueden tener concentraciones importantes de $\mathrm{Cu}$ y $\mathrm{Ni}(\mathrm{hasta}$ 1,38\% de $\mathrm{Cu}+\mathrm{Ni}$ ) and $\mathrm{Co}$ (hasta 0,53\%). Ocurrencias de costras de $\mathrm{Mn}$ ricas en Co han sido reportadas alrededor de las islas Rapanui y Salas y Gómez, con contenidos de $\mathrm{Cu}+\mathrm{Ni}$ de hasta 0,3\%. Sitios con depósitos de fosforitas aparecen en estratos holocenos de la plataforma continental de Perú y norte de Chile, con un contenido promedio de $\mathrm{P}_{2} \mathrm{O}_{5}$ de 22,6\%. Depósitos de placeres de oro se encuentran en playas y canales del sur de Chile y podrían extenderse mar afuera, probablemente en cañones submarinos. Depósitos de placeres de titanio han sido evaluados en diferentes playas de Chile y también podrían continuarse mar afuera. Anomalías de platino han sido encontradas en canales y bahías del extremo sur de Chile. Muestras 
de mineralización de Sulfuros Masivos Volcanogénicos (VMS) no se conocen a la fecha en la ZEE de Chile. Sin embargo, muestras de depósitos hidrotermales, con potencial para mineralización polimetálica del tipo VMS, han sido colectadas alrededor de la isla Rapanui, y varias cadenas de montes submarinos e islas volcánicas indican condiciones favorables para la formación y preservación de estos depósitos. La información geológica, actualmente disponible, sobre el fondo marino de la ZEE de Chile es insuficiente para estimar el real potencial de sus recursos minerales no-energéticos.

Palabras clave: Depósitos minerales, Fondos marinos, Zona Económica Exclusiva de Chile.

\section{Introduction}

The interest for submarine mineral resources has expanded rapidly with improved understanding of the evolution of the Earth and the access of new technologies to explore the seabed, and due to the need for reposition of land resources (e.g., Lusty and Murton, 2018). This has allowed the development of the coastal and shallow water $(<50 \mathrm{~m}$ depth) mining business, including exploitation of placer, lime, coal, gravel and sand deposits, among others (Lenoble et al., 1995; Rona, 2008). In deep oceanic areas, no exploitation is known, although large and high-grade ore bodies, such as volcanogenic massive sulfide deposits and Fe-Mn nodules/crusts have been explored and evaluated (Cronan, 1980, 2000; Rona, 2008; Hein et al., 2013; Lusty and Murton, 2018; www.nautilusminerals.com; http://deep.green/ (Last visit 25/12/2019)). Several countries have studied their Exclusive Economic Zones (EEZs, 200 nautical miles or $c a .360 \mathrm{~km}$ from the coast line) and the International Seabed Authority (ISA) has so far given 29 exploration contracts in the Pacific, Atlantic and Indian oceans, for more than 390.000 square miles for 15 years each one (ISA, 2018). Apparently, these areas until today have not resulted in economically viable projects because of grade/tonnage relationship of ore-bodies, extraction/processing costs and environmental restrictions. The ecological impacts and regulation challenges of the future ocean mining have been recently discussed by Jones et al. (2018) and Lodge and Verlaan (2018), respectively.

The Chilean offshore includes a large variety of landscapes and geotectonic features (Fig. 1). The Chilean EEZ has an area of 3,681,989 $\mathrm{km}^{2}$, which is almost five times larger than the area of the continental territory (Figs. 1-2). At present, the knowledge about the potential for mineral resources, especially nonenergetic, in this EEZ and surrounding sectors, is scarce and scattered, and exploration efforts have been few and poorly documented. This is largely due to the wealth of mineral resources being exploited on land and the high cost of marine geological exploration, which usually include access to deep drill holes, shallow gravity cores in sediments $(<10 \mathrm{~m}$ length) and grab samples of seabed sediments or rocks. In the Chilean EEZ, 9 deep drill holes have been obtained from the Oceanic Drilling Program, in expeditions during years 1991-1992 and 2002 (Fig. 1; http://www-odp.tamu.edu/publications (Last visit 01/04/2019)). The first expedition considered sites located at depths from 1,239 to 2,760 m b.s.l. and drilled holes up to 62 to $743 \mathrm{~m}$ long, whereas the second campaign considered sites at depths from 489 to $4,069 \mathrm{~m}$ b.s.l. and drilled holes up to 125 to $375 \mathrm{~m}$ long. These drill holes did not indicate relevant nonenergetic mineral occurrences.

Energetic mineral resources have been studied in the continental shelf and slope off centralsouthern Chile. Petroleum and gas are exploited in the continental domain of the Magallanes area and these resources have been explored and evaluated in many offshore basins with at least 18 deep wells and seismic surveys; no economically positive results have been concluded (e.g., Mordojovich, 1981; González, 1989; Zanella et al., 2013). Methane hydrates have been sampled from deep drill holes (ODP 1991-1992 expedition; Behrmann et al., 1992; Bangs et al., 1993; Brown et al., 1996) and shallow-gravitational cores (Coffin et al., 2007), and important lateral extensions of these resources have been indicated from seismic reflection studies (Rodrigo et al., 2004, 2009; Vera and Díaz-Naveas, 2010; Vargas-Cordero et al., 2010, 2016, 2018; Villar-Muñoz et al., 2018).

Here, we present a review of the non-energetic mineral resources recognized in the Chilean EEZ seabed and their geotectonic and metallogenic setting, which is based on a georeferenced database and complemented with updated bathymetric information, provided by world radar data and oceanographic vessel surveys (e.g., Zapata, 2001; Amante and Eakins, 2009; Becker et al., 2009). 


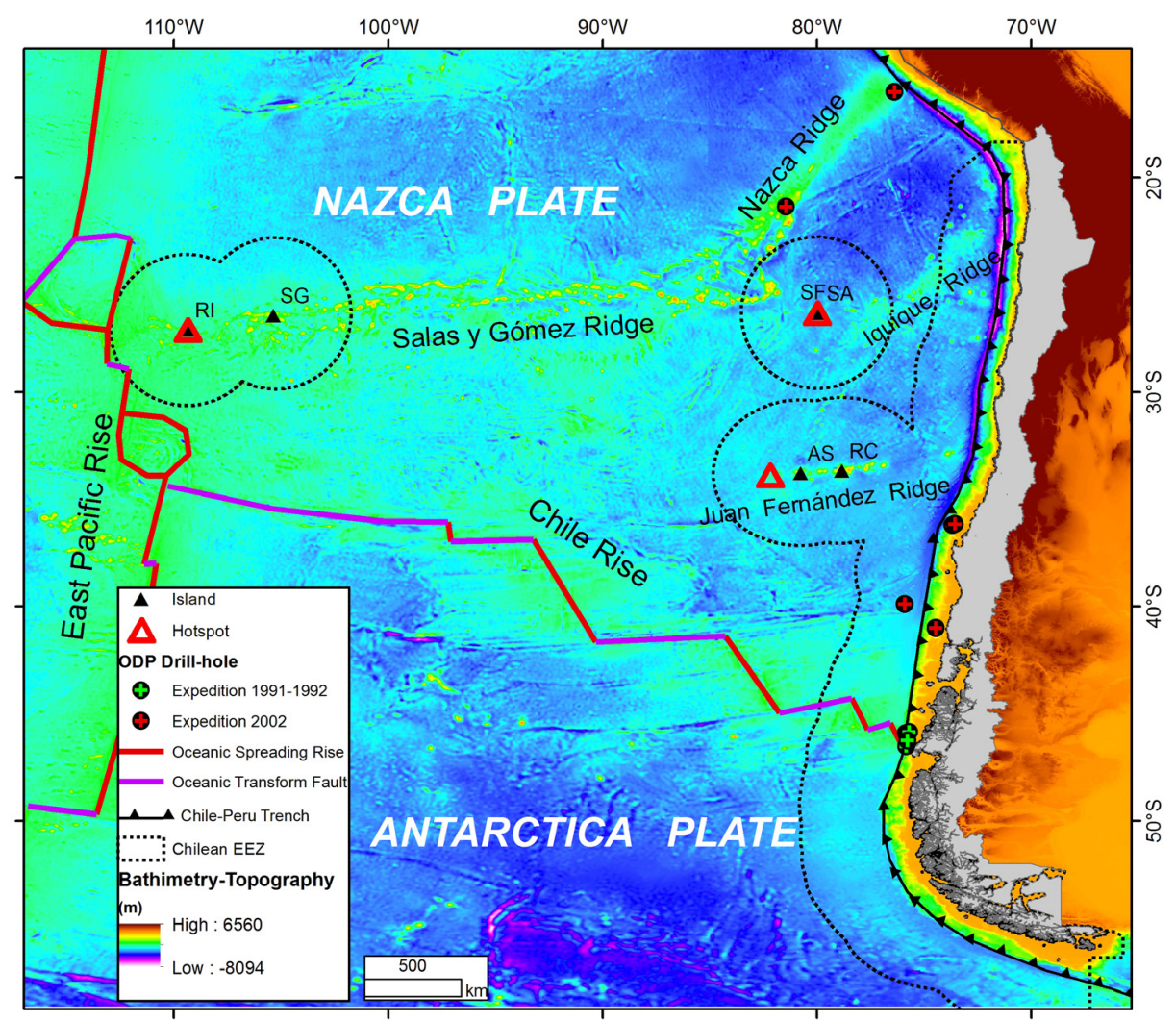

FIG. 1. Bathymetry of the eastern Pacific Basin (Amante and Eakins, 2009) and main tectonic features and boundary types of the Nazca, Antarctica and Pacific plates (Bird, 2003). Hotspots from Sandwell et al. (2005) and Rodrigo and Lara (2014). ODP sites from http://www-odp.tamu.edu/publications (Last visit 01/04/2019). The outline of the Chilean 200 nautical miles Economic Exclusive Zone (EEZ, from United Nations Conventions, 1998) is also shown. RI: Rapanui island; SG: Salas y Gómez island; SF: San Félix island; SA: San Ambrosio island; AS: Alejandro Selkirk island; RC: Robinson Crusoe island.

\section{Geotectonic setting}

The bathymetry of the Chilean offshore is controlled by the interaction of the Nazca, Pacific, Antarctic and the South American tectonic plates (Bird, 2003; Fig. 1). It includes a large part of the east Pacific Ocean basin, various submarine volcanic chains, several oceanic islands, submarine seamounts and plateaus, and the Chile-Peru trench, followed to the east by the continental margin (e.g., Amante and Eakins, 2009; Becker et al., 2009; Díaz-Naveas and Frutos, 2010). The continental margin is 10 to $120 \mathrm{~km}$ wide and formed by the slope and shelf, which are cut by submarine canyons, especially off central and southern Chile. The two major submarine volcanic chains are the Salas y Gómez Ridge and Chile Rise, oriented approximately E-W (Fig. 1). In between them, the Juan Fernández Ridge is located towards the continent. The Salas y Gómez Ridge continues to the NE, as the Nazca Ridge, and to the E, as the Iquique Ridge (Fig. 1).

The East Pacific Rise and Chile Rise are seismicallyactive and correspond to divergent plate margins characterized by an extensional tectonic setting, with abundant tholeiitic magmatic activity and high thermal gradients (Bird, 2003). In the Nazca plate, between the East Pacific Rise and the Chile-Peru trench, there are many volcanogenic intraplate environments. These include aseismic ridges, oceanic plateaus and seamounts, and deep-water abyssal conditions, up to $5,000 \mathrm{~m}$ depth, dominated by low sedimentation rates (Fig. 1; Bird, 2003; Becker et al., 2009; DíazNaveas and Frutos, 2010). The oceanic islands and some of the seamounts have been generated by typical exponents of tholeiitic and alkaline intraplate volcanism, associated in part with hot spots (González-Ferrán, 


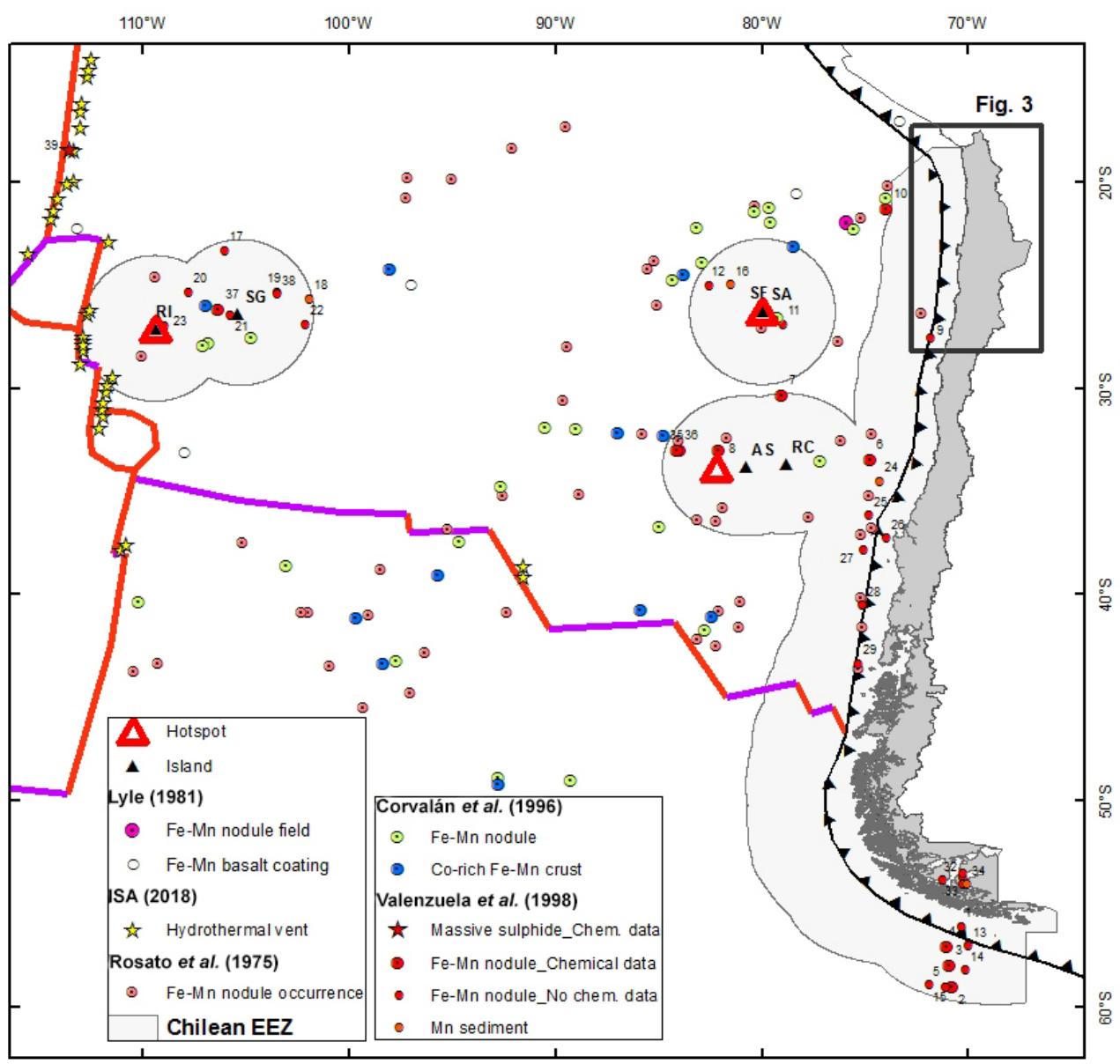

FIG. 2. Fe-Mn nodule and crust samples and hydrothermal vent samples available in the Chilean offshore. Fe-Mn nodule sites from Rosato et al. (1975), Lyle (1981), Valenzuela et al. (1984) and Corvalán et al. (1996). Co-rich Fe-Mn-crust sites from Corvalán et al. (1996) and hydrothermal vent sites from ISA (2018). Sites of Corvalán et al. (1996) were taken from a map figure at 1:10.000.000 scale. Sites of Rosato et al. (1975) and Lyle (1981) were taken from map figures at approximate scale of 1:40.000.000. Location of the sites of Valenzuela et al. (1984) are from a table with coordinates (except sites 22 and 26 that were taken from a 1:8.000.000 scale map); the sites have the same labels as in table 1. For others symbols see legend of figure 1. Figure 3 location is shown in the upper right corner.

1987; Lara, 2010 and references therein; Rodrigo and Lara, 2014). Three Quaternary hotspots have been indicated in this part of the Nazca plate (Fig. 1; Sandwell et al., 2005). The Chile-Peru trench is the result of the convergence between the Nazca and South American plates that generates a compressive tectonic setting (Fig. 1; Bird, 2003; Sandwell et al., 2005). The continental shelf is characterized by shallow waters (up to $300 \mathrm{~m}$ depth) and moderate to high sedimentation rates. The global wind and marine circulation generates the Humboldt Current, which is cold and northward-directed, coming from the Antarctic Ocean (Montecino and Lange, 2009).

\section{Metallogenetic setting}

Mero (1965), Cronan (1980, 2000), Rona (2008), Hein et al. (2013) and Lusty and Murton (2018) among others have presented complete summaries to explain the occurrence and distribution of the submarine mineral deposits in the world. They have shown up the relevance of deposits of Fe-Mn nodule/ crust, volcanogenic massive sulfide (VMS), placer, phosphorite and salt. Fe-Mn nodules and crusts are precipitates that occur in abyssal environments on ocean floors, volcanic seamounts and plateaus (Cronan, 2000; Rona, 2008; Hein et al., 2013). Fe-Mn 
nodules can reach $20 \mathrm{~cm}$ in diameter, their dominant mineral phase is todorokite and occur predominantly on the surface of sediment-covered abyssal plains at water depths of approximately 3,500 to $6,500 \mathrm{~m}$. Mn concentrations can be high $(>30 \%)$ in diagenetic nodules, such as in the Peru Basin (Von Stackelberg, 2000; Hein et al., 2013). Nodules are abundant in areas with oxidizing bottom seawaters, low sedimentation rates, and abundant sources of nucleation. They acquire metals from seawater (hydrogenetic) and pore fluids (diagenetic). The Fe-Mn crusts occur mainly in areas where oxygen rich waters are cold and sedimentation rates are extremely low. The highest concentrations of crusts are found in equatorial areas of the Pacific and Atlantic Ocean basins (Cronan, 2000; Hein et al., 2013; Lusty et al., 2018). They are normally found in depths between 400 and 7,000 m b.s.l., being thicker $(<25 \mathrm{~cm})$ and metal enriched at depths between 800 and 2,500 m b.s.l. Respect to the Earth mean composition, oceanic ferromanganese crusts are highly enriched in $\mathrm{Co}, \mathrm{Te}, \mathrm{Mo}, \mathrm{Bi}, \mathrm{Pt}, \mathrm{W}, \mathrm{Zr}$, $\mathrm{Nb}, \mathrm{Y}$ and rare-earth elements (REE). In contrast to Fe-Mn nodules, crusts acquire metals only from seawater (hydrogenetic), and have typically three to six times less Mn than Fe (Hein et al., 2013). Crusts are more enriched in Co and REE than nodules but less enriched in $\mathrm{Cu}$ and $\mathrm{Ni}$. The diagenetic component of nodules increases their growth rates to about 2 to 50 times faster than those of Fe-Mn crusts. Hein et al. (2013) have highlighted that Fe-Mn nodules and crusts have more $\mathrm{Tl}, \mathrm{Mn}, \mathrm{Te}, \mathrm{Ni}, \mathrm{Co}$ and $\mathrm{Y}$ than the global terrestrial reserve base for those metals, and that the Fe-Mn nodules and crusts are strongly enriched in $\mathrm{Cu}, \mathrm{Mo}, \mathrm{Bi}, \mathrm{Pt}, \mathrm{W}, \mathrm{Zr}, \mathrm{Li}, \mathrm{Nb}$ and REEs relative to the Earth's lithosphere. At present in the world, the richer and larger Fe-Mn nodule/crust deposits are located in the NE and Central Pacific zones (Hein et al., 2013; http://deep.green/ (Last visit 25/12/2019)).

The VMS deposits are polymetallic, lenticular, stratiform massive bodies hosted in volcanic or volcano-sedimentary rock sequences deposited on ocean floors (Franklin et al., 1981, 2005; Cronan, 2000; Hannington et al., 2005; Rona, 2008). VMS deposits commonly contain $\mathrm{Cu}, \mathrm{Zn}, \mathrm{Au}, \mathrm{Ag}$, and Fe. The volcanic activity and water depth are two factors controlling hydrothermal development on the sea floor (Butterfield et al., 1997). In the oceanic ridges and volcanic intraplate seamounts-islands, the magmatic activity favors the hydrothermal activity and generation of VMS deposits. The origin of these deposits is related to submarine volcanic-exhalative processes, i.e., hydrothermal vents. At present, the most interesting underwater VMS prospects are located in the mid-Atlantic Ocean and western Pacific Ocean (Rona, 2008; www.nautilusminerals. com (Last visit 25/12/2019)).

Marine environments characterized by shallow waters and high sedimentation rates favor the formation of phosphate and other mineral deposits as a result of sediments and chemical components carried by rivers (Veeh et al., 1973; Riggs, 1979; Burnett, 1990; Rona, 2008). Phosphorite deposits consist of a variety of phosphorous-bearing minerals that distinguish from other sedimentary deposits or rocks by their high content of phosphorus pentoxide $\left(\mathrm{P}_{2} \mathrm{O}_{5}\right)(5-40 \%$; Riggs, 1979). Phosphorite deposits occur on continental shelves, submarine plateaus and banks, formed by carbonate cementation and replacement, and on islands and atolls where the source of phosphorus is mainly guano and rock phosphate nearby. Most phosphorite deposits in the world have a Miocene age (Rona, 2008).

Placer type deposits are accumulations of valuable minerals formed by gravitational separation (or mechanical concentration) during transport in sedimentary processes by fluid flow, typically water. Marine placer deposits, of heavy minerals such as diamond, gold, tin, thorium, titanium, zirconium, monazite and others, have been exploited in continental shelves ( $<50 \mathrm{~m}$ depth). Underwater diamond placer mines are known in the southeastern coast of Africa, gold placer mines in Alaska and titanium-zirconium placer mines in India (Lenoble et al., 1995; Cronan, 2000; Rona, 2008).

\section{Ferromanganese nodules}

In the Nazca Plate off Chile, Fe-Mn nodules have been sampled at least since 1960's (e.g., Mero, 1965). Sediments containing more than $12 \% \mathrm{Fe}$ and a few $\mathrm{Fe}-\mathrm{Mn}$ nodules are found on the East Pacific Rise (Böstrom, 1970). Rosato et al. (1975) reported 53 points with occurrence of Fe-Mn nodules in seabed sediments from the Nazca Plate off Chile (Fig. 2). These authors describe the nodules as "occurrence of manganiferous concretions, not including micronodules". No more detail is indicated and chemical analyses are not available. Some tens samples of seabed sediments in the Nazca Plate off Chile were also recovered by Dymond (1981), who indicated a strong enrichment in $\mathrm{Mn}(>10 \%), \mathrm{Fe}, \mathrm{Cu}$, and $\mathrm{Zn}$ in the East Pacific Rise 
as result of hydrothermal activity. Additionally, some samples of Fe-Mn basalt coatings and one sample of an "extensive nodule field" (off N Chile, at $c a .22^{\circ} \mathrm{S}$ ) have been reported by Lyle (1981) (Fig. 2). The nodule sample contains low $\mathrm{Mn} / \mathrm{Fe}$ ratio (ca. 1$)$, high $\mathrm{Ce}$ and $\mathrm{Co}$ contents, and relatively low $\mathrm{Cu}, \mathrm{Ni}$, and $\mathrm{Zn}$ abundances, and is interpreted as formed by hydrogenous precipitation (Lyle, 1981). The metal source of the sediments of the eastern part of the Nazca Plate would have been originated by hydrothermal solutions derived from the interaction of seawater with basalt crust, during crystallization of solid phases at low temperatures (Kulm et al., 1983).

Valenzuela et al. (1984) selected and studied 38 oceanographic sites with presence of $\mathrm{Fe}-\mathrm{Mn}$ nodules or micronodules, and Mn-bearing sediments, in the Chilean EEZ (Fig. 2; Table 1). These sampled sites proceeded from the Scripps Databank (ONU) and the "Instituto Oceanográfico e Hidrográfico de la Armada de Chile" Databank. A density of 4 to $5 \mathrm{~kg} / \mathrm{m}^{2}$ has been estimated for these nodules/ micronodules (Valenzuela, 1986). Ten sites had 43 chemical analyses for major and some minor elements (Fig. 2; Table 1; Valenzuela et al., 1984). Interesting Fe-Mn nodule sites are present in an abyssal plain off northernmost Chile (Loa River latitude), around the Juan Fernández Ridge, near the Salas y Gómez Island, and south of Magallanes (Fig. 2). The most relevant sampled site is located at the latitude of the Loa River mouth $\left(21.3^{\circ} \mathrm{S}\right)$, where a nodule site occurs at $4332 \mathrm{~m}$ depth and contains $0.65 \% \mathrm{Cu}, 0.73 \% \mathrm{Ni}$ and $0.81 \% \mathrm{Zn}$ (combined $\mathrm{Cu}+\mathrm{Ni}$ grade of $1.38 \%$; site 10 in table 1 and Fig. 2). This site is situated at $217 \mathrm{~km}$ from the nodule field sampled by Lyle (1981) and at 122 and $140 \mathrm{~km}$ from two samples of Rosato et al. (1975) (Fig. 2) suggesting that all of this large area can contain metal bearing Mn nodules.

Around the Juan Fernández Ridge and completely inside the Chilean EEZ, a Fe-Mn nodule field is found at 3650-3953 $\mathrm{m}$ depth, with a combined $\mathrm{Cu}+\mathrm{Ni}$ grades of 0.25 to $0.96 \%$ (sites $6,7,8,35$ and 36 in table 1 and Fig. 2; Valenzuela et al., 1984). In the Site 7, nodules are formed by cryptomelane, pyrolusite, Mn amorphous aggregates and limonites, and chemical data for 17 subsamples (cores, rims and different nodules) obtained by at least three different laboratories, indicate mean concentrations of $\mathrm{Fe}$ up to $19.8 \%$, Mn up to $18.32 \%$ and Co up to $0.305 \%$ (Table 1; Valenzuela et al., 1984). In this site, Ni is overestimated at 2.6 times larger by one of the laboratories, due to probably problems in heterogeneity of subsamples or in analytical procedures. In the Site 6 , the mean value of $\mathrm{Mn}$ is $36.7 \%$ ( 7 analyses), and in the Site 35, mean values of $\mathrm{Fe}$ is $19.25 \%$ and Mo is $0.048 \%$ (Table 1). In addition, in this area, Rosato et al (1975) also reported numerous sites with Fe-Mn nodules (Fig. 2). Near the Salas y Gómez Island, Site 37 (at 2,890 m depth) yielded $0.6 \% \mathrm{Cu}+\mathrm{Ni}$ and $18.8 \% \mathrm{Fe}$ (Table 1 and Fig. 2; Valenzuela et al., 1984). South of Magallanes, samples at depths from 3,767 to 4,007 m indicate grades of $\mathrm{Cu}+\mathrm{Ni}$ of 0.3 to $0.57 \%$ and mean values of Co of 0.163 to $0.532 \%$ (sites 2, 3 and 4 in table 1 and figure 2; Valenzuela et al., 1984); one analysis from the Site 3 yielded $1.51 \%$ of Co.

More recently, based on bottom samples and photographies from numerous sources, 24 sites of $\mathrm{Fe}-\mathrm{Mn}$ "recovered" nodules have been reported in the Chilean offshore (Fig. 2; Piper et al., 1987; Corvalán et al., 1996). Six of these sites are situated in the Chilean EEZ and close to sites of Rosato et al. (1975), Lyle (1981) and Valenzuela et al. (1984). Several other sites are in the proximities of the Chilean EEZ. A hundred of sea bottom photographs did not indicate nodules (Corvalán et al., 1996).

\section{Ferromanganese crusts}

In Chile's EEZ, Co-rich Fe-Mn crusts and metalliferous sediments have been reported in the volcanic belt and oceanic floor around the Salas y Gómez and Rapanui islands (Figs. 1-2; Valenzuela, 1986; Flückiger and Valenzuela, 1994). The metalliferous sediment samples have yielded Mn contents greater than $10 \%$ and $\mathrm{Cu}+\mathrm{Ni}$ contents of 0.25 to $0.3 \%$ (Valenzuela, 1986; Flückiger and Valenzuela, 1994). There, the sample depths vary from 2,089 to $4,720 \mathrm{~m}$ b.s.l. (Valenzuela et al., 1984). Additionally, 12 sites of Co-rich Fe-Mn crusts, with $\mathrm{Co} *(=\operatorname{Cox} 51.23$ / $(\mathrm{Fe}+\mathrm{Mn}))<1.0$, have been indicated for the Chilean offshore, and 4 of these sites are located in the Salas y Gómez ridge (Figs. 1-2; Manheim and LaneBostwick, 1989; Corvalán et al., 1996). The results suggest that all of the submarine volcanic chain, from Rapanui Island to San Ambrosio Island, for more than $3,000 \mathrm{~km}$ long at approximate mean depths of 2,000 m b.s.l., can be a favorable environment for formation and preservation of Fe-Mn crusts.

\section{Phosphorite deposits}

There is evidence of submarine phosphorite nodules in Holocene sediments of the continental 
TABLE 1. SAMPLE SITES WITH AVAILABLE CHEMICAL ANALYSIS AND COORDINATES (FROM VALENZUELA ET $A L$., 1984).

\begin{tabular}{|c|c|c|c|c|c|c|c|c|c|c|c|c|c|}
\hline ID Site & 2 & 3 & 4 & 6 & & 7 & & 8 & 10 & 35 & 36 & 37 & 39 \\
\hline Latitude S & 59.017 & 57.983 & 57.083 & 33.517 & & 30.392 & & 33.05 & 21.338 & 33.042 & 33.033 & 26.2 & 18.512 \\
\hline Longitude W & 70.75 & 70.883 & 70.983 & 74.717 & & 78.98 & & 82.05 & 73.908 & 83.942 & 84.05 & 106.3 & 113.477 \\
\hline Depth (m) & 3,797 & 4,007 & 3,767 & 3,953 & & 3,820 & & 3,881 & 4,332 & 3,650 & 3,873 & 2,890 & - \\
\hline $\begin{array}{l}\text { Number of chemical } \\
\text { analyses }\end{array}$ & 1 & 6 & 3 & 7 & 2 & 6 & 9 & 4 & 1 & 2 & 1 & 1 & 1 \\
\hline Laboratory & & & & & & UCH & CIMM & & & & & & CIMM \\
\hline \multicolumn{14}{|l|}{ wt.\% } \\
\hline $\mathrm{Fe}$ & 24.56 & 17.957 & 18.02 & 4.086 & 13.465 & 19.802 & 17.689 & 16.375 & 6.7 & 19.25 & 6.7 & 18.8 & 33.8 \\
\hline Mn & 16.63 & 15.183 & 7.993 & 36.729 & 18.32 & 14.638 & 13.267 & 17.067 & 10.1 & & 10.1 & 10.6 & 0.002 \\
\hline $\mathbf{N i}$ & 0.2 & 0.435 & 0.357 & 0.098 & 0.735 & 0.295 & 0.27 & 0.518 & 0.73 & 0.285 & 0.5 & 0.43 & $<0.002$ \\
\hline $\mathrm{Cu}$ & 0.1 & 0.135 & 0.153 & 0.156 & 0.22 & 0.238 & 0.194 & 0.3 & 0.65 & 0.175 & 0.23 & 0.17 & 27.5 \\
\hline Co & 0.24 & 0.532 & 0.163 & 0.013 & 0.085 & 0.305 & 0.212 & 0.108 & 0.04 & 0.105 & 0.14 & 0.14 & 0.13 \\
\hline Zn & 0.07 & 0.084 & 0.068 & 0.031 & - & 0.052 & 0.054 & 0.08 & 0.81 & 0.065 & 0.07 & - & 0.064 \\
\hline $\mathbf{P b}$ & 0.28 & 0.11 & 0.07 & 0.015 & - & 0.1 & 0.082 & - & 0.03 & - & 0.06 & - & $<0.005$ \\
\hline Mo & - & - & - & - & - & 0.0264 & 0.024 & - & - & 0.048 & - & - & 0.033 \\
\hline $\mathrm{Cu}+\mathrm{Ni}$ wt.\% & 0.3 & 0.57 & 0.51 & 0.254 & 0.955 & 0.533 & 0.464 & 0.818 & 1.38 & 0.46 & 0.73 & 0.6 & 27.5 \\
\hline
\end{tabular}

The ID sites are the same of figure 2. Sites 2 to 37 are from Fe-Mn nodules in the Chilean EEZ, whereas the Site 39 is from a massive sulfide located outside this zone. The columns show the mean value of several analyses of subsamples per site (from 1 to 17 analyses). Site 7 has 17 subsamples distributed in three groups analyzed by different laboratories. The available laboratories are indicated for two groups of these subsamples (Site 7) and for the Site 39. Coordinates are in Provisional South American Datum 1956.

UCH: Laboratory of the Departamento de Geología, Universidad de Chile.

CIMM: Laboratory of the Centro de Investigación Minera y Metalúrgica, Chile. 
shelf of Peru and northern Chile, based on sediment gravity core sampling, at seabed depths from 120 to $446 \mathrm{~m}$ b.s.1. (Veeh et al., 1973; Burnett, 1977; 1990). 15 samples were recovered, of which 6 are situated in the north Chilean EEZ (Fig. 3). The phosphorite nodules are mainly associated with laminated, organic-rich, diatomaceous ooze. The mineralogical and geochemical studies of samples, including microprobe analyses, show that the largest component of phosphorites is fluorapatite, and $\mathrm{P}_{2} \mathrm{O}_{5}$ contents vary between 6 and 29\%, with an average content of $22.6 \%$ (Burnett, 1977). The phosphorite deposition off Peru and Chile is attributed to the seawater upwelling related to the Humboldt Current (Veeh et al., 1973; Burnett, 1990).
On the continental portion of northern Chile, specifically in the Mejillones and Caldera localities, Valdebenito and Gutiérrez (1979) have shown the existence of phosphate deposits (Fig. 3). These oredeposits are hosted in Neogene sedimentary rocks accumulated in a shallow marine basin environment and crop today as uplift terraces. The phosphate deposit at Caldera has an average grade of $18 \% \mathrm{P}_{2} \mathrm{O}_{5}$ in a horizon approximately $1 \mathrm{~m}$ thick (Valdebenito and Gutiérrez, 1979). The presence of these ore-deposits on land in Neogene sedimentary strata suggests continuation to submarine environments. Thus, as phosphorites occur in Holocene marine beds, it indicates a large potential for economic volumes and concentrations in the continental shelf of northern Chile (Fig. 3).

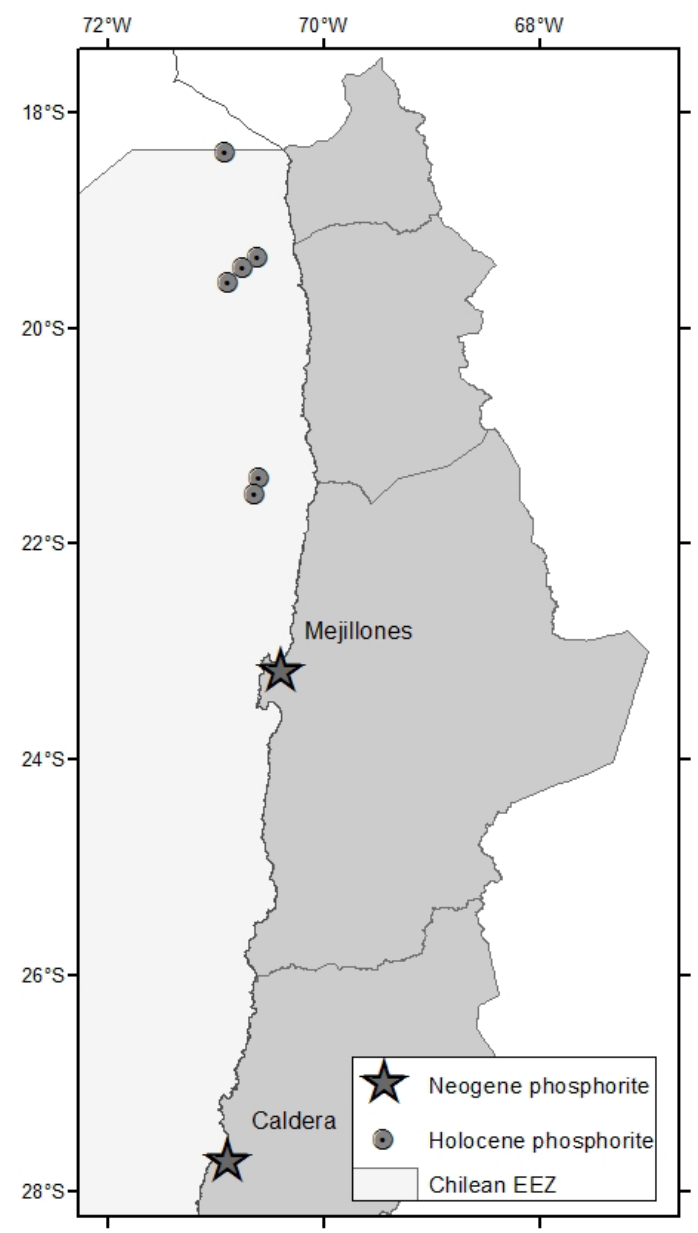

FIG. 3. Map of northern Chile showing presence of Holocene submarine phosphorite occurrences sampled and studied by Burnett (1977). Two Neogene phosphorite deposits are shown on land, at Mejillones and Caldera, from Valdebenito and Gutiérrez (1979). 


\section{Placer deposits}

In Chile there is evidence of gold and titanium accumulation in some beaches and channels along the coast. These placers are related to the coastal wave reworking of sedimentary deposits derived from the metamorphic-granitic basement rocks or glacialalluvial-fluvial sediments. Artisanal exploitation of beach gold placers has historically occurred in Huentelauquén (Coquimbo Region, northern Chile) and southern Chile, particularly around the Chiloé island area (at Cucao, Carelmapu and Comau beaches) and in the islands and channels of the Magallanes Region (Ruiz and Peebles, 1988; Greiner, 1991; Portigliati, 1999; Cronan, 2000). In the western coast of Chiloé Island, the detrital gold is in black sands, with magnetite, ilmenite, zircon, garnet and monazite (Ruiz and Peebles, 1988). Underwater sampling from the erosional canyon offshore Cucao, at depths from 300 to $1,200 \mathrm{~m}$, has demonstrated, with chemical analyses, gold anomalies and suggests probable extension of gold placer mineralization in the seabed (Carlos Gherardelli, 2008; personal communication to B.T.).

In the Magallanes Region, southernmost Chile, the littoral gold placer deposits are strongly related to reworking of Pleistocene moraine deposits (Greiner, 1991). In 1988-1991, in the Magallanes channel and Nassau bay, Anglo American Corporation detected anomalies of detrital gold in the seabed (Cronan, 2000, in Pineda et al., 2002). Thus, the submarine canyons and channels appear to be good concentrators of detrital gold. On the other hand, Rona (2008) suggests that all narrow western shelf of South America may have significant potential for gold placer deposits due to the presence of very large and rich, Mesozoic-Cenozoic gold deposits, which are epithermal-type and porphyry-type.

Titanium placer deposits have been identified locally in beaches and dunes along the Chilean coast (Fuller et al., 2004) in the so called "black sands". For example, certain sectors of the beaches located in Caldera, in the Atacama Region in northern Chile, have a $\mathrm{TiO}_{2}$ grade of $51.4 \mathrm{wt} \%$ (Valderrama et al., 2005). These placers may continue to the offshore with favorable exploration potential. Finally, regarding the platinum, some dragged and piston corer samples, collected in southernmost Chile, Magallanes Region (Beagle channel and Nassau bay), have yielded anomalous concentrations of this element, with 10 to $70 \mathrm{ppb}$, but no gold anomalies have been reported (Contardo, 2001; Pineda et al., 2002).

\section{Polymetallic volcanogenic massive sulfide deposits (VMS)}

No samples of VMS mineralization are known in the Chilean EEZ to date. According to ISA (2018), 32 sites of "hydrothermal vents and sampling locations", with potential for polymetallic volcanogenic massive sulfide deposits (VMS), exist in the Chilean offshore and surrounding areas (Fig. 2). These sites are situated around the East Pacific Rise and Chile Rise, of which five are inside the Chile's EEZ, to the east of Rapanui Island. The localities could contain polymetallic mineralization related to VMS deposits, but no more information is available. Outside the Chilean EEZ, 1,000 km approximatively to the northwest of Rapanui Island, Valenzuela et al. (1984) reported one sample from a hydrothermal vent (of 10x10x12 $\mathrm{cm}^{3}$ ), with massive sulfide mineralization, that indicates a primary mineralogical composition of chalcopyrite, pyrite, sphalerite and bornite, and a chemical composition of $27.5 \% \mathrm{Cu}, 33.8 \% \mathrm{Fe}$ and $35.3 \% \mathrm{~S}$ (site 39 in Fig. 2 and table 1). Additional to oceanic spreading settings, in the Chilean EEZ several seamount and volcanic island chains, such as the Salas y Gómez (or Rapanui-San Ambrosio) and Juan Fernandez ridges, and three Quaternary hotspots close to oceanic islands (Fig. 2; Sandwell et al., 2005), are environments with high potential to host VMS deposits. In Chile's EEZ, there are more than 118 seamounts (Yañez, et al., 2009) and the area around the Quaternary hotspots could host young polymetallic VMS type mineralization.

\section{Conclusions}

Although the submarine mining in the world has not been developed yet, the local geological knowledge is crucial to explore and discover new mineral resources and to be prepared for an eventual future exploitation. The Chilean offshore has a variety of submarine landscapes and tectonic, magmatic, hydrothermal and oceanographic conditions, with potential to host different types of non-energetic mineral resources. The Chilean EEZ is almost five times larger than the continental area, and for example, this zone around the San Félix and San Ambrosio islands is similar to all of the Chilean 
"Norte Grande". Available submarine geological information was compiled, standardized and integrated in a georeferenced database (in part, showed in table 1 and plotted in figures 2 and 3). Sampling in the seabed, for exploration of nonenergetic mineral resources, has only included shallow cores on sediments and dredges, in some places of the oceanic area (Rosato et al., 1975; Burnett, 1977; Lyle, 1981; Dymond, 1981; Valenzuela et al., 1984; Corvalán et al., 1996) and in inner waters of southern Chile (channels and fjords; Valenzuela $e t$ al., 1984; Contardo, 2001; Pineda et al., 2002). The studies are very limited in terms of the geochemical and mineralogical analyses. Our review indicates that the most significant non-energetic mineral resources in the Chilean EEZ correspond, in order of importance today, to: Fe-Mn nodules and crusts, gold and titanium placers, phosphorites and, potentially, VMS deposits.

Fe-Mn nodule sites occur largely in abyssal plains, seamounts and around volcanic islands, at depths from 2,890 to $4,332 \mathrm{~m}$ b.s.l. The most interesting sites are located off northernmost Chile, around the Juan Fernández and Rapanui islands, and south of Magallanes, and they can have important concentrations of $\mathrm{Cu}$ and $\mathrm{Ni}$ (up to $1.38 \% \mathrm{Cu}+\mathrm{Ni}$ ) and $\mathrm{Co}$ (mean values up to $0.53 \%$ ). Co-rich $\mathrm{Mn}$ crusts have been reported around the Rapanui and Salas y Gómez islands with contents of $\mathrm{Cu}+\mathrm{Ni}$ up to $0.3 \%$; these could be extended in the submarine volcanic chain until the San Ambrosio island, for more than $3,000 \mathrm{~km}$ at approximate mean depths of 2,000 $\mathrm{m}$ b.s.l. Unfortunately, samples of Fe-Mn nodules and crusts have not been analyzed by minor, trace and critical elements such as Tl, Te, Y, Bi, Pt, W, Zr, Li, Nb and REE. Phosphorite occurrences have been documented in Holocene submarine sediments, in the continental shelf of northern Chile, with average $\mathrm{P}_{2} \mathrm{O}_{5}$ content of samples of $22.6 \%$. Phosphorite deposits also occur on land, in Neogene sedimentary strata of the Mejillones and Caldera areas, and these may have possible extensions offshore; therefore, a large potential for economic volumes and concentrations of these deposits in the continental shelf of northern Chile is indicated. Although, Cronan (2000) has estimated that submarine phosphorite mining would be unlikely in the near future due to the large reserves of this resource on land.

Artisanal exploitation of gold placer deposits in some beaches and channels of southern Chile, particularly in the western Chiloé Island and Magallanes Region, suggests that gold concentrations may also extend offshore. Titanium placer deposits have been evaluated in different beaches and dunes of Chile and could be continued offshore. Platinum anomalies have been found in channels and bays of southernmost Chile (Magallanes Region). No samples of VMS deposits are known to date in the Chilean EEZ. However, some samples of hydrothermal vents, with potential for polymetallic VMS mineralization, have been identified in the Chilean EEZ around the Rapanui Island and several seamount and volcanic island chains, as the Salas y Gómez and Juan Fernández ridges and East Pacific and Chile rises, are environments with high potential to host these types of ore deposits. Additionally, in Chile's EEZ there are at least three Quaternary hotspots, which could host polymetallic VMS type mineralization and/or increase the metal input to the Fe-Mn nodule and crust mineralization-type. Therefore, further geological studies are needed in the large Chilean EEZ to assess its potential of non-energetic mineral resources.

\section{Acknowledgments}

This work was partially founded by AMTC (CONICYT/ PIA Project AFB180004). We thank to the Engineer W. Rocher for initial motivation on the Chilean submarine mining subject. Fructiferous discussions were held with colleagues R. Fernández and C. Rodrigo. A preliminary version of this paper was reviewed by J. Díaz-Naveas and L. Lara. Edition was made by F. Henríquez and W. Vivallo.

\section{References}

Amante, C.; Eakins, B.W. 2009. ETOPO1 1 Arc-Minute Global Relief Model: Procedures, Data Sources and Analysis. NOAA Technical Memorandum NESDIS NGDC-24. National Geophysical Data Center, NOAA. doi: 10.7289/V5C8276M.

Bangs, N.B.; Sawyer, D.S.; Golovchenko, X. 1993. Free gas at the base of the gas hydrate zone in the vicinity of the Chile Triple Junction. Geology 21: 905-908.

Becker, J.J.; Sandwell, D.T.; Smith, W.H.F.; Braud, J.; Binder, B.; Depner, J.; Fabre, D.; Factor, J.; Ingalls, S.; Kim, S-H.; Ladner, R.; Marks, K.; Nelson, S.; Pharaoh, A.; Sharman, G.; Trimmer, R.; Von Rosenburg, J.; Wallace, G.; Weatherall, P. 2009. Global Bathymetry and Elevation Data at 30 Arc Seconds Resolution: SRTM30_PLUS. Marine Geodesy 32 (4): 355-371. 
Behrmann, J.H.; Lewis, S.D.; Musgrave, R.; Bangs, N.; Boden, P.; Brown, K.; Collombat, H.; Didenko, A.N.; Didyk, B.M.; Froelich, P.N.; Golovchenko, X.; Forsythe, R.; Kurnosov, V.; Lindsley-Griffin, N.; Marsaglia, K.; Osozawa, S.; Prior, D.; Sawyer, D.; Scholl, D.; Spiegler, D.; Strand, K.; Takahashi, K.; Torres, M.; Vega-Faundez, M.; Vergara, H.; Waseda, A. 1992. Chile Triple Junction. Proceedings ODP Initial Reports (Pt A) 141: 1-708.

Bird, P. 2003. An updated digital model of plate boundaries, Geochemistry Geophysics Geosystems 4 (3): 1027. doi: 10.1029/2001GC000252.

Böstrom, K. 1970. Submarine volcanism as a source for iron. Earth Planet. Science Letters 9: 348-354.

Brown, K.M.; Bangs, N.L.; Froelich, P.N.; Kvenvolden, K.A. 1996. The nature, distribution, and origin of gas hydrate in the Chile Triple Junction region. Earth and Planetary Science Letters 139: 471-483.

Burnett, W.C. 1977. Geochemistry and origin of phosphorite deposits from off Peru and Chile. Geological Society of American Bulletin 88: 813-823.

Burnett, W.C. 1990. Phosphorite growth and sediment dynamics in the Modern Peru shelf upwelling system. In Phosphate Deposits of the World. Genesis of Neogene to Recent Phosphorites (Burnett, W.C.; Riggs, S.R.; editors), Cambridge University Press, Cambridge 3: 62-72.

Butterfield, D.; Jonasson, I.; Massoth, G.; Feely, R.; Roe, K.; Embley, R.; Holden, J.; McDuff, R.; Lilley, M.; Delaney., R. 1997. Seafloor eruptions and evolution of hydrothermal fluid chemistry, Philosophical Transactions of the Royal Society of London Series a-Mathematical Physical and Engineering Sciences 355: 369-386.

Coffin, R.; Pohlman, J.; Gardner, J.; Downer, R.; Wood, W.; Hamdan, L.; Walker, S.; Plummer, R.; Gettrust, J.; Díaz, J. 2007. Methane hydrate exploration on the mid Chilean coast: A geochemical and geophysical survey. Journal of Petroleum Science and Engineering 56 (1): 32-41.

Contardo, X. 2001. Estudio Textural, Mineralógico y Geoquímico de los Sedimentos Marinos del Sector de Canal Beagle y Bahía Nassau, XII Región de Magallanes, Chile (69 $15^{\prime}-66^{\circ} 20^{\prime} \mathrm{W}$ y 54 50' $-56^{\circ} 00^{\prime} \mathrm{S}$ ). Memoria (Inédito) para optar al título de Geóloga. Universidad de Concepción, Departamento de Ciencias de la Tierra: $186 \mathrm{p}$.

Corvalán, J.; Bellizzia, A.; Pimentel, N.; Buenaventura J.; Guild, P.; Piper, D.; Swint-Iki, T.; Luepke, G.; Gryc, G.; McCoy, F.; Sullivan, L.; Manheim, F.; Lane-Bostwick,
C. 1996. Explanatory notes for the minerals-resources map of the Circum-Pacific region, southeast quadrant. Circum-Pacific map project, scale 1:10.000.000, U.S. Geological Survey: 30 p. California. doi: 10.3133/cp44.

Cronan, D.S. 1980. Underwater Minerals. Academic Press: 362 p. London.

Cronan, D.S.; 2000. Handbook of Marine Mineral Deposits. CRC Press, Boca Raton: 442 p. Florida.

Díaz-Naveas, J.; Frutos, J. 2010. Geología Marina de Chile. Comité Oceanográfico Nacional de Chile-Pontificia Universidad Católica de Valparaíso-Servicio Nacional de Geología y Minería de Chile: 115 p.

Dymond, J. 1981. The geochemistry of Nazca plate surface sediments: An evaluation of hydrothermal, biogenic, detrital, and hydrogenous sources. In Nazca plate: Crustal formation and Andean convergence (Kulm, L.D.; Dymond, J.; Dasch, E.J.; Hussong, D.M.; Roderick, R.; editors). Geological Society of America Memoir 154: 133-173.

Flückiger, M.; Valenzuela, E. 1994. Impacto de la minería submarina en la producción minera de Chile. In Congreso Geológico Chileno, No. 7, Actas 1: 286-289.

Franklin, J.M.; Sangster, D.M.; Lydon, J.W. 1981. Volcanic-associated massive sulfide deposits. In Economic Geology Seventy-Fifth Anniversary Volume (Skinner, B.J.; editor). Society of Economic Geologists: 485-627.

Franklin, J.M.; Gibson, H.L.; Jonasson, I.R.; Galley, A.G. 2005. Volcanogenic Massive Sulfide Deposits. In Economic Geology $100^{\text {th }}$ Anniversary Volume (Hedenquist, J.W.; Thompson, J.F.H.; Goldfarb, R.J.; Richards, J.P.; editors): 523-560.

Fuller, D.; Fuller, J.; Cabrera, N.; Recabarren, P.; Riquelme, C. 2004. Titanium Minerals in Chile. In Congreso CONAMET/SAM.

González, E. 1989. Hydrocarbon reseources in the coastal zone of Chile. In Geology of the Andes and its relation to hydrocarbon and mineral resources (Ericksen, G.E.; Cañas, M.T.; Reinemund, J.A.; editors). CircumPacific Council for Energy and Mineral Resources, Earth-Science Series 11: 383-404.

González-Ferrán, O. 1987. Evolución geológica de las islas chilenas en el océano Pacífico. In Islas oceánicas chilenas. Conocimiento científico y necesidades de investigaciones (Castilla, J.C.; editor). Universidad Católica de Chile: 37-54. Santiago.

Greiner, G. 1991. Características y distribución de los placeres auríferos de Chile. Empresa Nacional de Minería (ENAMI). In Gisements alluviaux d'or: 39-52. La Paz. 
Hannington, M.D.; de Ronde, C.E.J.; Petersen, S. 2005. Sea-floor tectonics and submarine hydrothermal systems. Economic Geology, 100 ${ }^{\text {th }}$ Anniversary Volume: 111-141.

Hein, J.R.; Mizell, K.; Koschinsky, A.; Conrad, T. 2013. Deep-ocean mineral deposits as a source of critical metals for high- and green-technology applications: Comparison with land-based resources. Ore Geology Reviews 51: 1-14.

ISA, 2018. International Seabed Authority, United Nations. Maps repository in http://www.isa.org.jm (Last visit 30/10/2018).

Jones, D.O.B.; Amon, D.J.; Chapman, A.S.A. 2018. Mining deep-ocean mineral deposits: what are the ecological risks? Elements 14: 325-330.

Kulm, L.D.; Dymond, J.; Scheidegger, K.F. 1983. Nazca Plate and Andean Forearc Studies. Geodynamics Series. Geodynamics of the Eastern Pacific Region, Caribbean and Scotia Arcs, Volume 9: 83-94.

Lara, L. 2010. Las islas oceánicas de Chile. Geología Marina de Chile. In Comité Oceanográfico Nacional de Chile (Díaz-Naveas, J.; Frutos, J.; editors). Pontificia Universidad Católica de Valparaíso-Servicio Nacional de Geología y Minería de Chile: 44-47.

Lenoble, J.P.; Augris, C.; Cambon, R.; Saget, P. 1995. Marine Mineral Occurrences and Deposits of the Economic Exclusive Zones, MARMIN: A Data Base: Editions IFREMER: 274 p.

Lodge, M.W.; Verlaan, P.A. 2018. Deep-sea mining: international regulatory challenges and responses. Elements 14: 331-336.

Lusty, P.A.J.; Murton, B. 2018. Deep-Ocean Mineral Deposits: Metal Resources and Windows into Earth Processes. Elements 14: 301-306.

Lusty, P.A.J.; Hein, J.R.; Josso, P. 2018. Ferromanganese crusts: Earth's storehouse for critical metals. Elements 14: 313-318.

Lyle, M. 1981. Formation and growth of ferromanganese oxides on the Nazca plate. In Nazca plate: Crustal formation and Andean convergence (Kulm, L.D.; Dymond, J.; Dasch, E.J.; Hussong, D.M.; Roderick, R., editors). Geological Society of America Memoir 154: 269-293.

Manheim, F.T.; Lane-Bostwick, C.M. 1989. Chemical composition of ferromanganese crusts in the world ocean: a review and comprehensive database: U.S. Geological Survey Open-File Report 89-020: 450 p.

Mero, J.L. 1965. The Mineral Resources of the Sea. Elsevier: 312 p. Amsterdam.

Montecino, V.; Lange, C.B. 2009. The Humboldt Current System: Ecosystem components and processes, fishe- ries, and sediment studies. Progress in Oceanography 83: 65-79.

Mordojovich, C. 1981, Sedimentary basins of Chilean Pacific offshore, in Energy resources of the Pacific region: American Association of Petroleum Geologists Studies in Geology 12: 63-68.

Pineda, V.; Contardo, X.; Alfaro, G.; Helle, J. 2002. Caracterización textural, mineralógica y geoquímica de los sedimentos del Canal Beagle y Bahía Nassau, XII Región de Magallanes, Chile. CIMAR-Fiordos 3. Ciencia y Tecnología del Mar 25 (1): 5-21.

Piper, D.Z.; Swint-Iki, T.R.; McCoy, F.W. 1987. Distribution of ferromanganese nodules in the Pacific Ocean: Chemie der Erde 46: 171-184.

Portigliati, C. 1999. Los placeres auríferos de Chile. Servicio Nacional de Geología y Minería, Informe Registrado IR-99-16: 131 p., 1 map 1:2.500.000. Santiago.

Riggs, S.R. 1979. Petrology of the Tertiary phosphorite system of Florida. Economic Geology 74: 195-220.

Rodrigo, C.; Lara, L. 2014. Plate tectonics and the origin of the Juan Fernández Ridge: analysis of bathymetry and magnetic patterns. Latin American Journal of Aquatic Research 42 (4): 907-917.

Rodrigo, C.; González, A.; Vera, E.; Díaz, J.; Morales, E. 2004. Hidratos de gas submarino en el margen chileno: análisis sísmico preliminar del reflector simulador del fondo (BSR). GEOS 24: 116-117.

Rodrigo, C.; González-Fernández, A.; Vera, E. 2009. Variability of the bottom simulating reflector (BSR) and its association with tectonic structures in the Chilean margin between Arauco Gulf $\left(37^{\circ} \mathrm{S}\right)$ and Valdivia $\left(40^{\circ} \mathrm{S}\right)$. Marine Geophysical Researches 30: 1-19.

Rona, P. 2008. The changing vision of marine minerals. Ore Geology Reviews 33: 618-666.

Rosato, V.; Kulm, L.D.; Derks, S. 1975. Surface sediments of the Nazca Plate. Pacific Science 29 (1): 117-130. Great Britain.

Ruiz, C.; Peebles, F. 1988. Geología de los yacimientos metalíferos de Chile. Editorial Universitaria: 334 p.

Sandwell, D.; Anderson, D.; Wessel, P. 2005. Global tectonic maps. In Plates, plumes, and paradigms (Foulger, G.R.; Natland, J.H.; Presnall, D.C.; Anderson, D.L.; editors). Geological Society of America Special Paper 388: 1-10.

Valdebenito, E.; Gutiérrez, A. 1979. Exploración de fosforitas en la península de Mejillones. In Congreso Geológico Chileno, No. 2: 307-328. Arica.

Valderrama, L.; Poblete, R.; Contreras, C. 2005. Caracterización y concentración de muestras de arenas de Caldera, Región de Atacama. Revista 
Facultad de Ingeniería, Universidad de Atacama 19: $38-44$.

Valenzuela, E. 1986. Recursos metálicos del suelo y subsuelo de la Zona Económica Exclusiva Chilena. In Jornadas Nacionales de Cultura, No. 11, Universidad de Playa Ancha de Ciencias de la Educación: 492-504. Viña del Mar.

Valenzuela, E.; Mpodozis, C.; Morales, E.; Parra, J.C.; Ugarte, G.; Tello, A.R.; Quiñones, C. 1984. Anteproyecto para la evaluación del potencial minero del fondo oceánico del mar de Chile. Informe Inédito $\mathrm{N}^{\circ}$ 970, 2 tomos, 6 mapas. Informe final del Proyecto CONICYT 242-83, Departamento de Geología, Universidad de Chile, Archivos Nacionales.

Vargas-Cordero, I.; Tinivella, U.; Accaino, F.; Loreto, M.F.; Fanucci, F.; Reichert, C. 2010. Analyses of bottom simulating reflections offshore Arauco and Coyhaique (Chile). Geo-Marine Letters 30: 271-281.

Vargas-Cordero, I.; Tinivella, U.; Villar-Muñoz, L.; Giustiniani, M. 2016. Gas hydrate and free gas estimation from seismic analysis offshore Chiloé island (Chile). Andean Geology 43 (3): 263-274. doi: 10.5027/andgeoV43n3-a02.

Vargas-Cordero, I.; Tinivella, U.; Villar-Muñoz, L.; Bento, J.P. 2018. High Gas Hydrate and Free Gas Concentrations: An Explanation for Seeps Offshore South Mocha Island. Energies 11: 3062.

Veeh, H.; Burnett, W.C.; Soutar, A. 1973, Contemporary phosphorite on the continental margin of Peru. Science 181: 845-847.

Vera, E.; Díaz-Naveas, J. 2010. Recursos geoquímicos del fondo marino-Hidratos de gas submarinos en el margen chileno. In Geología Marina de Chile (DíazNaveas, J.; Frutos, J.; editors), Comité Oceanográfico Nacional de Chile-Pontificia Universidad Católica de Valparaíso-Servicio Nacional de Geología y Minería de Chile: 62-65.

Villar-Muñoz, L.; Bento, J.P.; Klaeschen, D.; Tinivella, U.; Vargas-Cordero, I.; Behrmann, J.H. 2018. A first estimation of gas hydrates offshore Patagonia (Chile). Marine and Petroleum Geology 96: 232-239. doi: 10.1016/j.marpetgeo.2018.06.002.

Von Stackelberg, U. 2000. Manganese nodules of the Peru Basin. In Handbook of Marine Mineral Deposits (Cronan, D.S.; editors). CRC Press, Boca Raton: 197-238. Florida.

Yañez, E.; Silva, C.; Vega, R.; Espíndola, F.; Álvarez, L.; Silva, N.; Palma, S.; Salinas, S.; Menschel, E.; Häussermann, V.; Soto, D.; Ramírez, N. 2009. Seamounts in the southeastern Pacific Ocean and biodiversity on Juan Fernandez seamounts, Chile. Latin American Journal of Aquatic Research 37 (3): 555-570.

Zanella, A.; Cobbold, P.; Rojas, L. 2013. Beef veins and thrust detachments in Early Cretaceous source rocks, foothills of Magallanes Austral Basin, southern Chile and Argentina: Structural evidence for fluid overpressure during hydrocarbon maturation. Marine and Petroleum Geology 55: 250-261. doi: 10.1016/j. marpetgeo.2013.10.006.

Zapata, R. 2001. Estudio batimétrico del margen chileno. Tesis para optar al grado de Magíster en Ciencias, Mención Geofísica aplicada (Inédito). Universidad de Chile, Departamento de Geofísica, Facultad de Ciencias Físicas y Matemáticas: 113 p.

Manuscript received: December 18, 2018; revised/accepted: March 26, 2019; available online: September 30, 2019. 